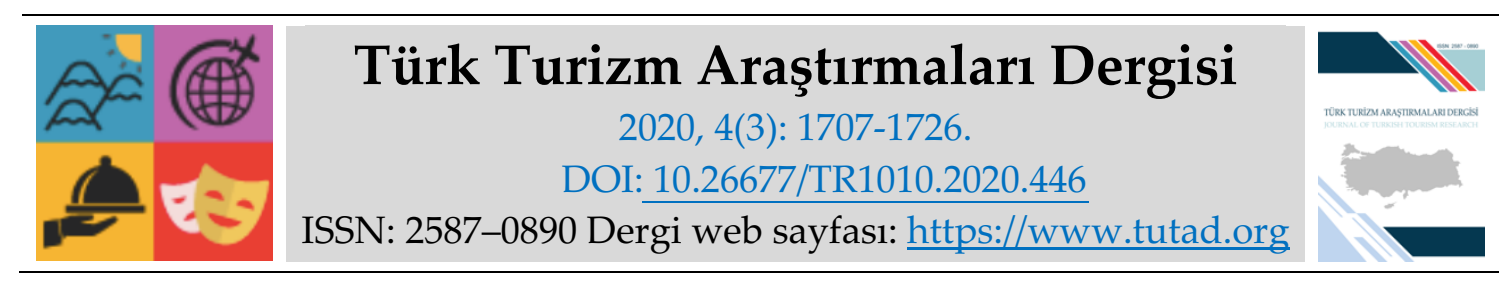

ARASTIRMA MAKALESI

\title{
Yavaş Şehir (Cittaslow) Ağına Katılımın Destinasyona Etkileri: Göynük Örneği
}

Doç. Dr. Mustafa SANDIKCI, Afyon Kocatepe Üniversitesi, Turizm Fakültesi, Afyonkarahisar, eposta: sandikcimustafa@hotmail.com ORCID: https://orcid.org/0000-0002-1437-2484

Aybike Nur ALBAYRAK, Afyon Kocatepe Üniversitesi, Sosyal Bilimler Enstitüsü, Afyonkarahisar, e-posta: aybikenurlbayrak@gmail.com

ORCID: https://orcid.org/0000-0001-8956-036X

Öz

Yavaş şehir ağına katılımın bir turizm destinasyonu olarak Göynük'e çevresel, ekonomik ve sosyo-kültürel etkilerinin ele alındığı bu çalışmada, veri toplama tekniği olarak anket kullanılmış ve kartopu örnekleme tekniğiyle belirlenen, Göynük'te ikamet eden yerel halktan 410 kişiye uygulanmıştır. Araştırma verilerinin analiz sürecinde ilk olarak geçerlilik ve güvenirlik analizleri gerçekleştirilmiş, devamında katılımcıların görüşlerinin ortaya konulması amaçlanmıştır. Katılımcıların demografik özellikleri bağlamında görüşleri arasındaki farklılıkları tespit edebilmek amaciyla iki grup için t-testi, ikiden fazla gruplar için ise Varyans Analizinden yararlanılmıştır. Farklılığa neden olan grupların tespitinde Tukey ve en küçük anlamlı farklılıklar (LSD) testlerinden faydalanılmıştır. Çalışmada elde edilen bulgulara göre katılımcılar yavaş şehir ağına katılımın turist sayısının artışında etkili bir model olduğunu ve Göynük'ün yavaşs şehir olmasından memnun olduklarını ifade etmişlerdir.

Anahtar Kelimeler: Yavaş Şehir, Cittaslow, Çevresel Etkiler, Ekonomik Etkiler, Sosyo-Kültürel Etkiler, Göynük.

Makale Gönderme Tarihi: 28.03.2020

Makale Kabul Tarihi: 01.07.2020

\section{Önerilen Atıf:}

Sandıkcı, M. ve Albayrak, A. N. (2020). Yavaş Şehir (Cittaslow) Ağına Katılımın Destinasyona Etkileri: Göynük Örneği, Türk Turizm Araştırmaları Dergisi, 4(3): 1707-1726.

(C) 2020 Türk Turizm Araştırmaları Dergisi. 


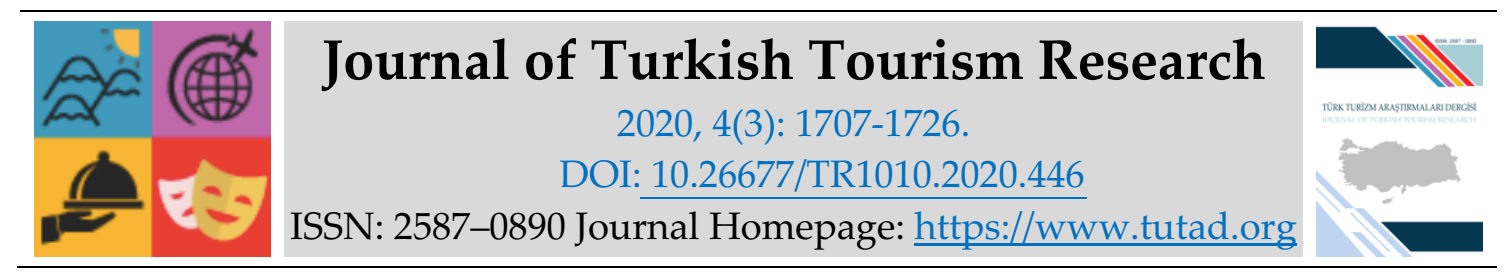

\title{
RESEARCH PAPER
}

\section{The Effects of Cittaslow Movement to the Destination: The Case of Göynük}

Associate Prof. Dr. Mustafa SANDIKCI, Afyon Kocatepe University, Faculty of Tourism, Afyonkarahisar, e-mail: sandikcimustafa@hotmail.com

ORCID: https://orcid.org/0000-0002-1437-2484

Aybike Nur ALBAYRAK, Afyon Kocatepe University, Social Sciences Institute, Afyonkarahisar, e-mail: aybikenurlbayrak@gmail.com

ORCID: https://orcid.org/0000-0001-8956-036X

\begin{abstract}
Through a survey of residents, this study examined the potential environmental, economic and socio-cultural effects of Cittaslow movement on the Göynük destination. A questionnaire was used as a data collection technique and it was applied to 410 residents in Göynük with snowball sampling. Reliability and validity analyses were conducted and in the ongoing process, the individual characteristics of the participants evaluated with frequency and percentage distributions and the mean and standard deviation values. The "t-test" and "Variance (Anova) Analysis" were used in order to compare participants' opinions in the context of demographics, and Tukey and LSD tests were used to determine the groups that caused differences. According to the findings, the participants stated that participation in the Cittaslow movement is an effective model for the increase in the number of tourists and they were pleased that Göynük was a slow city.
\end{abstract}

Keywords: Slow City, Cittaslow, Environmental Effects, Economic Effects, Socio-Cultural Effects, Göynük.

Received: 28.03 .2020

Accepted: 01.07.2020

\section{Suggested Citation:}

Sandikcl, M. and Albayrak, A. N. (2020). The Effects of Cittaslow Movement to the Destination: The Case of Göynük, Journal of Turkish Tourism Research, 4(3): 1707-1726.

(C) 2020 Türk Turizm Araştırmaları Dergisi. 


\section{Gíriş}

Günümüz dünyasında şehirler benzer görüntülere sahip olarak özgünlüklerini yitirmektedir. İtalya'da başlayan yavaş şehir hareketi, şehirlerin kendilerini değerlendirerek farklılıklarını ortaya koymalarını ve bu farklılıklarını koruması için projeler geliştirmesini istemektedir. Sürdürülebilir bir şehir modeli sunan, yaşam kalitesini arttırmaya dair hedefleri ve dünyanın bir miras değil emanet olduğu düşüncesi ile hareket eden yavaş şehir ağı dünya genelinde hızla yaygınlaşmaktadır (Berkün, 2018: 1418).

Cittaslow hareketi, yerel toplulukların refahını önceleyen, kendine yeten, sürdürülebilir; doğasına, gelenek ve göreneklerine, tarihi ve sanatsal değerlerine sahip çıkan, alt yapı sorunları olmayan, yenilenebilir enerji kaynakları kullanan, teknolojinin kolaylıklarından yararlanan kentlerin gerçekçi bir alternatif olacağı hedefini benimsemektedir (Baytok, Zorlu ve Avan, 2018: 135).

Yavaş şehir ağına katılımın destinasyon üzerindeki etkilerini Göynük özelinde ortaya koymayı amaçlayan bu çalışmada, öncelikle yavaş şehir kavramı, yavaş şehir ağının destinasyon üzerindeki çevresel, ekonomik ve sosyo-kültürel etkileri ve yavaş şehir Göynük ile ilgili kavramsal değerlendirmelere yer verilmiştir. Çalışmanın uygulama kısmında Göynük'te yerel halkın, yavaş şehir ağına katılımın destinasyona çevresel, ekonomik, sosyo-kültürel açıdan ne tür getirileri olduğu konusundaki düşüncelerinin ele alınması hedeflenmiştir. Literatürde yerel halkın yavaş şehir hareketine yönelik algılarını ortaya koymaya çalışan (Coşar, 2013; Çakıcı, Yenipınar ve Benli, 2014; Çıtak, 2016; Walker ve Lee, 2019a), yavaş şehir hareketinin destinasyon imajına (Çerçi, 2013) ve yaşam kalitesine (Hatipoğlu, 2015) etkilerini ele alan, yavaş şehir felsefesinin sürdürülebilir yerel gelişme üzerine etkilerini irdeleyen (Semmens ve Freeman, 2012; Presenza, Abbate ve Micera, 2015; Park ve Kim, 2016; Baytok, Zorlu ve Avan, 2018; Walker ve Lee, 2019b) çalışmalar bulunmakla birlikte, yavaş şehir hareketinin destinasyonlar üzerindeki çevresel, ekonomik ve sosyo-kültürel etkilerini ele alan çalışmalar kısıtlıdır. Buradan hareketle, araştırmanın amacında ifade edilen gerekçe ile literatüre katkı sağlanması hedeflenmektedir.

\section{KAVRAMSAL ÇERÇEVE}

Dünyada nüfusun büyük bir bölümü şehirlerde yaşamaktadır. Bu durumda kalabalık ve büyük şehirlerde yaşam kalitesinde düşüşler yaşanmakta bu yaşanan sorunlar da giderek karmaşık bir hale gelmektedir. İnsanlık geleceği için yaşanan bu şehir sorunlarına karşı çözüm arayışına girmiştir. Günümüz dünyasının ortaya çıardığı sorunlara dair üretilen çözümlerden biri yavaş şehir olarak adlandırılmıştır (Berkün, 2018: 1418).

Yavaş şehir (cittaslow) hareketi, 1999 yılında Greve in Chianti'nin eski belediye başkanı Paolo Saturnini'nin vizyonu doğrultusunda ortaya çıkmıştır. Paolo Saturnini yaşam kalitesini yükseltmek amacıyla kentlerin kendilerini değerlendirmelerini ve farklı bir kalkınma modeli ortaya koymaları fikrini ulusal boyuta taşıyarak bu idealler kısa zamanda Bra (Francesco Guida), Orvieto (Stefano Cimicchi) ve Positano (Domenico Marrone) belediye başkanları ve Slow Food başkanı Carlo Petrini tarafından benimsenmiştir. Günümüzde 30 farklı ülkede 264 üye şehre sahip bu hareketin amacı yavaş yemek (slow food) felsefesini kentsel boyuta taşırken günlük yaşamda ekogastronomi kavramlarını uygulamaktır (www.cittaslow.org). Diğer bir deyişle yavaş şehir hareketi, küreselleşmenin olumsuz etkilerine karşı çıan, dünyadaki bütün yerel kültürlerin korunmasını ve kültürlere sahip çıkılmasını destekleyen bir harekettir (Yazıcı ve Keba Ekici, 2017: 180).

Hareketin felsefesi ve amacı kısaca: "Yaşamın, yaşamaktan zevk alınacak bir hızda yaşanmasını 
savunmaktadır. Cittaslow hareketi, insanların birbirleriyle iletişim kurabilecekleri, sosyalleşebilecekleri, kendine yeten, sürdürülebilir, el sanatlarına, doğasına, gelenek ve göreneklerine sahip çıkan ama aynı zamanda alt yapı sorunları olmayan, yenilenebilir enerji kaynakları kullanan, teknolojinin kolayliklarından yararlanan kentlerin gerçekçi bir alternatif olacağı hedefiyle yola çıkmıştır." şeklinde belirtilmiştir (cittaslowturkiye.org).

Hareket, logo olarak turuncu bir salyangozu kullanmıştır. Salyangozun tercih edilme sebebi yavaşlık felsefesiyle salyangozun var olma biçiminin birbiriyle ilişkilendirilmesidir. Salyangoz, hem yavaşlığın hem dinginliğin temsilidir. Bununla birlikte salyangozlar, yuvalarını sırtlarında her yere taşımakta ve gittiklerinde arkalarında izlerini bırakmaktadırlar. Salyangozun hareketlerini belirleme yetisi ve hızı, insan doğasında akıl ve ağırbaşlılığın ifade ediliş biçimidir (Levent, 2019: 11).

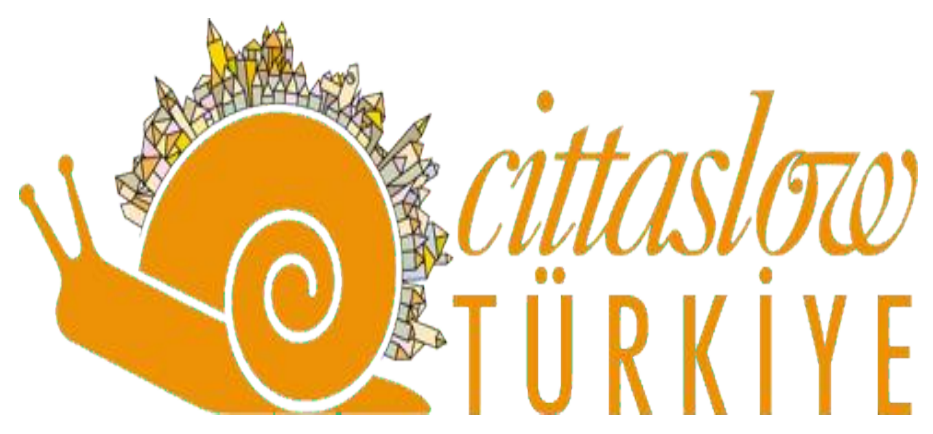

Resim 1: Cittaslow Logosu (cittaslowturkiye.org)

$\mathrm{Bu}$ şehirlerde, hayat belli bir düzen etrafında kuruludur. İnsanlar küçük yerel dükkan ve marketlerden ihtiyaçlarını karşılarken semt pazarlarında da doğal ve taze ürünlere kolayca ulaşabilmektedirler. Çevrede trafik, gürültü kirliliği ve bunların sebep olduğu stres ve rahatsız edici bir betonlaşma görüntüsüyle karşılaşmak çok mümkün değildir. Tüm bunlar, üretim yerine tüketime, koruma yerine kullanmayı özendiren metropol şehir mantığına çözüm olarak ortaya çıkan "Yavaş Şehir" (Coşar, 2019: 42) hareketidir.

Yavaş şehir hareketi, dünyada 30 ülkede 264 üye şehirde uygulanmaktadır. Türkiye'den 18 şehir yavaş şehir ağına dahildir. Türkiye'den üye şehirler; Ahlat (Bitlis), Akyaka (Muğla), Eğirdir (Isparta), Gerze (Sinop), Gökçeada (Çanakkale), Göynük (Bolu), Güdül (Ankara), Halfeti (Şanlıurfa), Köyceğiz (Muğla), Mudurnu (Bolu), Perşembe (Ordu), Seferihisar (İzmir), Şavşat (Artvin), Taraklı (Sakarya), Uzundere (Erzurum), Vize (Kırklareli), Yalvaç (Isparta), Yenipazar (Aydın)'dır.

Ağa katılacak şehirlerin nüfuslarının 50.000'den az olması ve şehir yönetiminin Cittaslow felsefesine uygun olması gerekmektedir. Ağa üye olmak için belirlenen kriterleri gerçekleştirmek için projeler geliştirmek ve uygulamak gerekmektedir. Şehirlerin 7 başlık 72 madde altında toplanan kriterler çerçevesinde yaptığ 1 çalışmalar puanlanmakta ve bir şehrin üye olması için 50 ve üzerinde puan alması gerekmektedir. Bu kriterler (cittaslowturkiye.org); çevre politikaları, altyapı politikaları, kentsel yaşam kalitesi politikaları, tarımsal, turistik, esnaf ve sanatkarlara dair politikalar, misafirperverlik, farkındalık ve eğitim için planlar, sosyal uyum ve ortaklıklardır.

Yavaş şehir felsefesinin destinasyonlar üzerinde birtakım etkileri söz konusudur. Bu etkiler arasında olumlu ya da olumsuz çevresel, ekonomik ve sosyo-kültürel etkiler sayılabilir. Yavaş şehir ağına katılırken sağlanması gereken şartlar bulunmaktadır ve bu şartların önemi belirtilmiş olup zorunlu olarak yerine getirilmeleri beklenmektedir. Çevre politikaları kapsamında hedef, 
çevreci bir belediye olarak halk sağlığını korumaktır. Yavaş şehir Göynük'te bu kapsamda sit alanlarında peyzaj ve asfalt çalışmaları yapılmış, katı atık depolama tesisi kurulmuş, mevcut içme suyu depoları yenilenmiş, sit alanlarında restorasyon çalışmaları yapılmış ve bisiklet yolu ve bisiklet park yerleri yapılacaktır (Akman, 2018: 90). Yavaş şehir ilkeleri arasında yer alan o yöreye ait değerler çerçevesinde yerel ürün kullanımı ve üreticilerin teşvik edilmesi, geleneksel, kültürel değerlerin korunması, tanıtımı ve pazarlanması yerel ekonomiye olumlu bir etki yapacaktır. Ayrıca üretimin doğal ürün elde etmek amacıyla yenilenebilir kaynak kullanarak ve geleneksel üretim yöntemleri kullanılarak yapılması ekonomik etkiler açısından olumlu bir gelişmedir (Kartal ve Öztürk, 2016: 350). Bunun yanında turistlere yönelik hazırlanan broşürler ve şehir içinde yönlendirici işaret ve tabelaların varlığı, şeffaf fiyat uygulaması sayesinde turistler ve yerel esnaf arasındaki güven duygusunun artması gibi faktörler bölgeye ekonomik bir katkı sağlayacaktır (Şahin ve Kutlu, 2014: 61).Yavaş şehir kriterleri arasında yer alan şehrin sahip olduğu değerlerin iyileştirilmesi, yavaş güzergahların mevcut olması, şehrin yaşanabilirliğinin arttırılması, yerel ürünlerin ticarileşmesi için alanların yaratılması, geleneksel iş tekniklerinin ve zanaatların değerinin arttıılması, yöre halkına yavaş şehir kavramı hakkında eğitim vermek, azınlıklara yönelik ayrımcılığa karşı çalışmalar, engelli kişilerin entegrasyonu, çocuk bakımının desteklenmesi, genç neslin istihdam durumu, yoksulluk, toplumsal ortaklıklar/sivil toplum kuruluşların mevcudiyeti, farklı kültürlerin entegrasyonu, Slowfood aktiviteleri ve kampanyaları için destek, doğal ve geleneksel yiyecekleri Slowfood veya diğer kurumlar ile destekleme gibi kriterler sosyal ve kültürel düzenin sağlanması, toplumun karar verme süreçlerine katılımının sağlanması için olumlu bir etkisi olacaktır (www. Cittaslowturkiye.org, Kartal ve Öztürk, 2016: 350). Göynük'te sosyo-kültürel anlamda halk yürüyüş güzergahları belirlenmiş, yöresel el sanatları merkezi açılmış ve işletmeci ve çalışanlara turizm eğitimi verilmiştir (Akman, 2018: 91).

Literatürde yavaş şehir konulu farklı açılardan ele alınmış çalışmalar mevcuttur. Bunlardan Acar (2018)'ın çalışmasında Türkiye' deki yavaş şehir uygulamalarının yerel turizm, ülke reklamları ile turizme katkısı değerlendirilmiştir. Numanoğlu ve Güçer (2018)'in çalışmasında yavaş şehir kavramının yavaş şehir olan Perşembe'ye olumlu ve olumsuz etkileri araştırılmıştır. Koç ve Baz (2020)'ın çalışmalarında Türkiye'deki yavaş şehirleri ele alarak üye olmayı düşünen diğer şehirlere rehber olması açısından yavaş şehir olabilme kriterlerinin uygulanma süreci ve sonrasındaki etkileri tüm yönleriyle incelenerek ortaya konulmuştur.

Yavaş şehir Göynük hakkında yapılmış olan çalışmalar incelendiğinde ise Dural ve Köseoğlu (2017) çalışmalarında yavaş şehir Göynük'ün bir destinasyon olarak tercih edilme sebepleri ve kentsel kimliğinin tercih edilme durumuna etkilerini ele almışlardır. Zengin ve Genç (2018)'in çalışmalarında, yavaş şehir olduktan sonraki süreçte Göynük'teki özel sektör işletmesi yöneticilerinin pazarlama faaliyetlerine bakış açılarında ne gibi değişiklikler yaşandığı ve gelecekte nasıl değişimler yaşanacağı incelenmiştir. Şengül, Bayhan ve Yücel (2018)'in çalışmalarında Göynük'te sürdürülebilir turizm gelişimi ve kalkınması yerel turizm paydaşlarının görüş ve değerlendirmeleriyle incelenmiştir. Sarıyıldız (2019)'ın çalışmasında ise, Göynük'te sakin kent algısı yerel halk, yerel işletmeciler ve belediye başkanı ile yapılan görüşmeler ile ortaya koyulmuştur.

\section{YÖNTEM}

\section{Araştırma Sahası: Yavaş Şehir Göynük}

Yurdumuzun Batı Karadeniz Bölgesi'nde yer alan Göynük ilçesi Bolu il merkezinin güneybatısında yer almaktadır. Yüzölçümü $1437 \mathrm{~km}^{2}$, denizden yüksekliği 720 m'dir. Göynük ilçesinin doğusunda Mudurnu, batısında Taraklı, kuzeyinde Akyazı ve güneyinde Nallıhan, 
Sarıcakaya ve Yenipazar ilçeleri bulunmaktadır. İlçe Bolu'ya 98 km, İstanbul'a $235 \mathrm{~km}$ ve Ankara'ya 290 km uzaklıktadır (Çetinkaya Usta, 2017: 15).

M.Ö. 13. yüzyılda Göynük'te en eski yerleşimin Frigler tarafından oluşturulduğu bilinmektedir. İlerleyen yıllarda bölge Lidyalılar, Persler, Bithynia Krallığı, Roma ve Bizans imparatorluğu hakimiyetinde kalmıştır. Son olarak bölge 1071 Malazgirt Savaşı' yla beraber Türk hâkimiyetine girmiştir. Türk hâkimiyetine girmesiyle beraber Göynük, kendi sınırındaki Taraklı, Yenice ve Mudurnu ile 1331-1332 yıllarında Osmanlı Devleti'ne katılmışlardır. Göynük, Osmanlı döneminde konaklama merkezi olarak kullanılmış ayrıca Bağdat yolu üzerinde bulunan Göynük, kervanlar için bir istasyon konumunda olmuştur. Göynük, Bolu Mutasarrıfllğına idari olarak 1865'te bağlanmıştır. 1923'te Cumhuriyetle beraber Bolu'nun ilçelerinden biri olmuştur ve Bolu'ya bağlı kalmaya devam etmiştir (Dural, 2019: 18).

Osmanlı şehir kültürünü yansıtan Göynük, tarihi ve kültürel birikimiyle Anadolu'nun nadir yerleşim merkezlerinden biridir. Farklı dönemlerden izler barındıran mimari eserleri, geçmişten günümüze süregelen el sanatları, gelenek görenekleri, kendine has yaşam alışkanlıkları ile zengin bir kültüre sahiptir (Çetinkaya Usta, 2017: 19). 1987 yılında kentsel sit alanı ilan edilen Göynük tarih, kültür, doğa ve inanç turizmi ile bir marka şehir (cittaslowturkiye.org) konumundadır. 2017 yılı Şubat ayında ise Yavaş Şehir Ağı'na kabul edilerek "yavaş şehir" unvanını almıştır.

Sahip olduğu değerler ile Göynük, önemli bir turizm potansiyeline de sahiptir. İlçe için önemli el sanatlarından olan ağaç oymacılığı eserleri ve tokalı örtme gibi eserlerin günümüzde hala üretimi yapılmakta ve ilçe ekonomisine katkı sağlamaktadır. Bununla birlikte şeker fasulyesi ve uğut marmeladı gibi yöreye has yiyecekler de ilçenin vazgeçilmezlerindendir (Çetinkaya Usta, 2017: 24).

Göynük'ün sahip olduğu önemli kültürel zenginliklerinden biri de 1464 yılında Fatih Sultan Mehmet tarafından yaptırıldığı kabul edilen Akşemseddin Türbesi'dir. Fatih Sultan Mehmed'in manevi hocası olan Akşemseddin Hazretleri'nin 15. yüzyılın ilk yarısında Göynük'e gelerek Göynük'te yaşaması, 1459 yılında burada vefat edip türbesinin yine burada bulunması ilçenin gelişmesine sebep olurken Göynük'ün önemli bir yerleşim yeri olduğunu göstermektedir. Akşemseddin Hazretleri her yıl Mayıs ayında yapılan tören ile anılmakta ve yöre de kültür turizminin gelişmesine katkıda bulunmaktadır. (Aktaş Yasa, 2013: 29).

İlçe ekonomisinde en önemli sektörler, ormancılık, tarım ve hayvancılık, özellikle de yumurta ve besi tavukçuluğudur. Kılavuzlar Köyü ile bazı köylerde ağaç oymacıllı̆ı el sanatlarında emek vererek alternatif geçim imkanları oluştururken, bir kısım yöre halkı ise arıcılıkla uğraşmaktadır (Kılıç Benzer, 2007: 100).

\section{Örneklem}

Yavaş şehir ağına katılımın Göynük'e etkilerini belirlemeyi amaçlayan bu çalışmada, Göynük'te yaşayan yerel halk çalışmanın evrenini oluşturmaktadır. 2019 yılı Adrese Dayalı Nüfus Kayıt Sistemi verilerine göre ilçe genel nüfusu 15.050 olup; kentsel nüfus 4.188, kırsal nüfus 10.862' dir (www.bolu.gov.tr). Evrenin tamamına ulaşmanın güçlüğü sebebiyle örneklem alma yoluna gidilmiştir. Çalışmada örnekleme yöntemi olarak kartopu örnekleme yöntemi uygulanmıştır. Araştırmada kartopu örnekleme tekniğinin seçilmesinin temel nedeni, araştırmacıların yavaş şehir ağına ilişkin bilgi sahibi olan ve yavaş şehir ağının bölgeye olası etkilerini değerlendirebileceğine inanılan kişilerin örneklem grubuna dahil edilmesi arzusudur. Veri toplama tekniği olarak yüz yüze anket kullanılmıştır. Hazırlanan anket formu 21 Kasım-13 Aralık 2019 tarihleri arasında 410 kişiye yüz yüze uygulanmıştır. Eksik veri, hatalı kodlama gibi nedenlerle 36 anket formu analizlere dâhil edilmemiştir. Sonuç olarak 374 anket formu üzerinden 
analizler gerçekleştirilmiştir.

Tablo 1. Katılımcıların Demografik Özellikleri

\begin{tabular}{|c|c|c|c|c|c|c|c|}
\hline Değişkenler & Gruplar & $\mathbf{n}$ & $\%$ & Değişkenler & Gruplar & $\mathrm{n}$ & $\%$ \\
\hline \multirow{2}{*}{ Cinsiyet } & Kadın & 162 & 43.3 & \multirow{4}{*}{ Gelir Düzeyi } & $2000 \mathrm{TL}$ ve altı & 137 & 36.6 \\
\hline & Erkek & 212 & 56.7 & & 2001 TL-3000 TL & 97 & 25.9 \\
\hline \multirow{8}{*}{ Meslek } & Esnaf & 43 & 11.5 & & 3001 TL-4000 TL & 60 & 16.0 \\
\hline & İsci & 52 & 13.9 & & 4001 TL ve üstü & 78 & 20.9 \\
\hline & F.v Hanımı & 60 & 16.0 & \multirow{6}{*}{ İkamet Süresi } & 1 vildan az. & 20 & 5.3 \\
\hline & Kamu Görevlisi & 69 & 18.4 & & $1-5$ y1l & 49 & 13.1 \\
\hline & Öğrenci & 80 & 21.4 & & 6-10 y1l & 27 & 7.2 \\
\hline & Ciftci & 30 & 8.0 & & $11-15$ vil & 62 & 16.6 \\
\hline & Emekli & 16 & 4.3 & & $16-24$ vil & 53 & 14.2 \\
\hline & Diŏger & 24 & 6.4 & & 25 vildan fazla & 163 & 436 \\
\hline \multirow{4}{*}{ Yaş } & 17 ve altı & 58 & 15.5 & \multirow{4}{*}{ Eğitim Durumu } & İlköğretim & 151 & 40.4 \\
\hline & $18-29$ yaş aralığ 1 & 88 & 23.5 & & Lise & 139 & 37.2 \\
\hline & $30-45$ yaş aralığ 1 & 129 & 34.5 & & Ön Lisans & 28 & 7.5 \\
\hline & $46-60$ yaş aralı̆̆ 1 & 67 & 17.9 & & Lisans & 52 & 13.9 \\
\hline
\end{tabular}

Tablo 1, katılımcıların demografik özelliklerini göstermektedir. Buna göre, katılımcıların \%56.7 ile çoğunluğu erkek olup \%34.5'i 30-45 yaş aralığında ve \%36.6'sının geliri 2000 TL ve altındadır. Katılımcıların \%43.6'sı 25 yıldan fazla zamandır Göynük'te ikamet etmektedir. Katılımcıların büyük çoğunluğunun uzun zamandır Göynük'te yaşadığı düşünülürse, yavaş şehir olmadan önce ve yavaş şehir olduktan sonraki durumunun değerlendirilmesinde ve yavaş şehir olmanın Göynük'e ne tür etkilerinin olduğunun gözlemlenmesinde yetkin oldukları ifade edilebilir.

\section{Ölçek}

İlgili literatürün gözden geçirilmesi sonucu hazırlanan anket formu, temel olarak iki bölümden oluşmaktadır. Birinci bölümde Göynük'te ikamet eden yerel halkın demografik özellikleri ve yaşam biçimiyle ilgili sorular yer alırken ikinci bölümde yavaş şehir ağına katılım, yavaş şehir ağına katılımın çevresel, ekonomik, sosyo-kültürel pozitif ve negatif etkileri ile ilgili sorular yer almaktadır. Yerel halkın yavaş şehir ağına katılan Göynük ile ilgili görüşlerinin ölçülmesinde $5^{\prime} l i$ Likert derecelemesinden yararlanılmıştır. İfadeler $1=$ Kesinlikle Katılmıyorum ve $5=$ Kesinlikle Katılıyorum aralığında puanlandırılmıştır. Anket formunda yer alan ifadelerden yavaş şehir ağına katılıma ilişkin ifadelerin oluşturulmasında Farhadi Andarabi (2012)'nin çalışmasından; yavaş şehir ağına katılımın çevresel, ekonomik ve sosyo kültürel pozitif ve negatif etkilerine ilişkin ifadeler ise Güneş (2014)'in farklı çalışmalardan derleyerek oluşturduğu ölçekten yararlanılarak hazırlanmıştır. Anket formu örneklem üzerinde uygulanmadan önce, anket formunda yer alan ifadelerin anlaşılabilirliğinin ve araştırma amacına uygunluğunun teyidi için alanında uzman akademisyenlerden yardım alınmıştır. Nihai değerlendirmelerin ardından anket formuna son hali verilmiştir. 


\section{Veri Analizi}

Araştırma verilerinin analiz sürecinde ilk olarak verilerin normal dağılımı analiz edilmiştir. Normal dağılım testi sonucunda Skewness $(-0.998,0.875)$ ve Kurtosis $(-1.013,0.380)$ katsayılarının normal dağılım sınırları içinde olduğu görülmüştür. Tabachnick ve Fidell (2013), Skewness ve Kurtosis değerlerinin -1.5 ile +1.5 aralığında olması halinde verinin normal dağılım gösterdiğini ifade etmektedirler. Buna göre, bu çalışmada verilerin normal dağılım gösterdiği ifade edilebilir. Ölçeğin faktör yapısını ortaya çıarmak amacıyla varimax rotasyonu ve temel bileşenler (principal components) yöntemi kullanılarak doğrulayıcı faktör analizi (DFA) uygulanmıştır. Ölçekteki yapıların daha önceki bir çalışmada ortaya konulması, güvenilirliği ve geçerliliğinin test edilmesi ve belirli bir olgunun belirgin etkilerinin ortaya koyulması nedeniyle keşfedici faktör analizi yapılmamıştır. DFA sonuçları ifadelerin yavaş şehir ağına katılım algısı, yavaş şehir ağına katılımın olumlu ve olumsuz çevresel, ekonomik ve sosyo-kültürel etkileri olmak üzere 7 boyut altında toplandığını göstermektedir. Veri analizinin takip eden aşamasında, araştırmada yararlanılan ölçekteki yapılar arasındaki ilişkiler Pearson Korelasyon Analizi ile belirlenmeye çalışılmıştır. Katılımcıların ifadelere ilişkin görüşlerinin ortaya konulması amacıyla ifadelere ilişkin aritmetik ortalama ve standart sapma katsayıları verilmiştir. Katılımcıların demografik özelliklerine göre yavaş şehir ağına katılıma ilişkin görüşleri arasındaki olası farklılıkları belirlemek için ikili grup karşılaştırmalarında t-test, ikiden fazla grup karşılaştırmalarında ise Anova analizinden yararlanılmıştır. Gruplardaki farklılıkların kaynağını belirlemek amacıyla Tukey ve $L S D$ testleri kullanılmıştır.

\section{BULGULAR}

Yavaş şehir ağına katılımın destinasyona etkilerini belirlemeye yönelik kullanılan ölçeğe ilişkin DFA sonucu elde edilen yedi boyut, boyutlara yönelik güvenilirlik katsayıları, her bir maddenin faktör yükleri ve toplam varyansı açıklama oranı Tablo 2' de gösterilmektedir. Güvenilirlik analizi sonucunda araştırmada kullanılan Cronbach's Alpha (CA) katsayısı ölçekte yer alan toplam 28 ifade için 0.860 olarak tespit edilmiştir. Boyutlar bağlamında güvenilirlik katsayılarının 0.665 ile 0.872 arasında değerler aldığı görülmektedir (Tablo 2). Sosyal bilimler alanında yapılan çalışmalarda ölçek güvenirliğini ifade eden Cronbach's Alpha kat sayısının 0 ile 1 arasında değişen değerler aldığı ve değerin 1'e yaklaşmasının güvenilirliği arttırdığı (Ural ve Kılıç, 2005: 219; Altunışık vd., 2012: 126) göz önüne alındığında; araştırma ölçeğinin güvenilirlik düzeyinin kabul edilebilir sınırlar içerisinde olduğunu, yavaş şehir ağına katılımın olumsuz ekonomik etkileri boyutu için (0.665) kısmen kabul edilebilir sınırlar içerisinde olduğunu söylemek mümkündür.

Araştırma ölçeğinin içsel tutarlılığını belirlemek amacıyla CA ile birlikte Composite Reliability (CR) katsayıları da hesaplanmıştır. CR katsayısının .780 ile .890 arasında olduğu görülmektedir (> .60). Yakınsak geçerlilik AVE (Average Variance Extracted) değerleri hesaplanarak belirlenmeye çalışılmıştır. Tablo 2' den anlaşıldığı üzere, AVE değerlerinin eşik sınır olarak kabul edilen .50 'den daha yüksek olması sebebiyle araştırmada yakınsak geçerliliğin sağlandığı ifade edilebilir. Araştırmada ayrıştırma geçerliliğinin belirlenmesi için ise korelasyon analizinden yararlanılmıştır. Tablo 3 incelendiğinde, faktör korelasyonlarının -.210 ile .616 arasında değiştiği, .90 olarak kabul edilen eşik sınırın altında olduğu görülmektedir. Buna göre, ayrıştırma geçerliliğinin bu çalışmada ilgili yapı için sağlandığı ifade edilebilir. 
Tablo 2. Araştırma Ölçeğine İlişkin Faktör Yapısı

\begin{tabular}{|c|c|c|c|c|}
\hline İfadeler & SFY & CA & AVE & CR \\
\hline Yavaş Şehir Algısı & & .848 & .533 & .817 \\
\hline Cittaslow, turist savısının artısında etkili bir modeldir. & .790 & & & \\
\hline Cittaslow. vörenin kalkınma ve gelismesi icin ivi bir modeldir. & .824 & & & \\
\hline Cittaslow, yerel halkın yaşam kalitesinin yükseltilmesi için iyi bir modeldir. & .728 & & & \\
\hline Yasadığım sehrin Cittaslow olmasından memnunum. & .548 & & & \\
\hline Yavas Sehir Ağına (Citta Slow) Katılımın Olumlu Cevresel Etkileri & & .869 & .561 & .834 \\
\hline Doğal cevrenin korunmasını ve gelisimini desteklemektedir. & .793 & & & \\
\hline Gelecek nesiller icin cevre kalitesini ivilestirmektedir. & .806 & & & \\
\hline Cevre bilincini artırmaktadır. & .775 & & & \\
\hline Tarihi bina ve vapıların korunmasını tesvik etmektedir. & .605 & & & \\
\hline Yavas Sehir Ağına (Citta Slow) Katılımın Olumsuz Cevresel Etkileri & & .855 & .646 & .879 \\
\hline Cevre kirliliğine (toprak, hava, su) neden olmaktadır. & .845 & & & \\
\hline Doğavı (bitkiler, havvanlar, ekosistem) olumsuz etkilemektedir. & .838 & & & \\
\hline Çarpık kentleșmeye neden olmaktadır. & .808 & & & \\
\hline Kalabalıklaşma, gürültü kirliliği, trafik sıkışılı̆ğı gibi problemler varatmaktadır. & .720 & & & \\
\hline Yavas Sehir Ağına (Citta Slow) Katılımın Olumlu Ekonomik Etkileri & & .869 & .515 & .856 \\
\hline Geleneksel ürünlerin üretimini sağlamaktadır. & .660 & & & \\
\hline Ekonomik kazanc sağlamaktadır. & .791 & & & \\
\hline Yerel ekonomivi desteklemektedir. & .757 & & & \\
\hline Yerel halk için veni is fırsatları varatmaktadır. & .655 & & & \\
\hline Bölgeve daha fazla vatırımın vapılmasını sağlamaktadır. & .539 & & & \\
\hline Yavas Sehir Ağına (Citta Slow) Katılımın Olumsuz Ekonomik Etkileri & & .665 & .544 & .780 \\
\hline Bölgedeki ürün ve hizmet fiyatlarını arttırmaktadır. & .666 & & & \\
\hline Bölgede hayat pahalılığına neden olmaktadır. & .837 & & & \\
\hline Yerel halk arasında ekonomik kazanc esitsizliği varatmaktadır. & .700 & & & \\
\hline Yavas Sehir Ağına (Citta Slow) Katılımın Olumlu Sosvo-Kültürel Etkileri & & .872 & .607 & .890 \\
\hline Kültürel aktivitelerin gelisimini sağlamaktadır. & .677 & & & \\
\hline Yerel halkın kültürel gelisimine katkı sağlamaktadır. & .828 & & & \\
\hline Yerel halkın yaşam kalitesini yükseltmektedir. & .823 & & & \\
\hline Yerel halkın eğlence serbest zaman değerlendirme olanaklarını arttırmaktadır. & .770 & & & \\
\hline Yavas Sehir Ağına (Citta Slow) Katılımın Olumsuz Sosvo-Kültürel Etkileri & & .849 & .616 & .864 \\
\hline Yerel halkın tutum ve davranıslarını olumsuz vönde etkilemektedir. & .720 & & & \\
\hline Kültürel değerlerin vok olmasına neden olmaktadır. & .853 & & & \\
\hline Yerel halkın turistik çekiciliklere ulaşımını zorlaştırmaktadır. & .788 & & & \\
\hline Suç, fuhuş, uyuşturucu gibi sosyal problemlere neden olmaktadır. & .774 & & & \\
\hline \multicolumn{2}{|c|}{ Cronbach's Alpha (Tüm ölçek için) } & & .860 & \\
\hline \multicolumn{2}{|c|}{ Toplam Varyansı Açılama Oranı } & & 71.055 & \\
\hline
\end{tabular}

SFY: Standart Faktör Yükü; CA: Cronbach's Alpha; AVE: Average Variance Extracted; CR: Composite Reliability 
Tablo 3.Korelasyon Analizi Sonuçları

\begin{tabular}{|c|c|c|c|c|c|c|c|}
\hline & Cittaslow & $\begin{array}{c}\text { Çev. } \\
\text { Olumlu }\end{array}$ & $\begin{array}{c}\text { Çev. } \\
\text { Olumsuz }\end{array}$ & $\begin{array}{c}\text { Eko. } \\
\text { Olumlu }\end{array}$ & $\begin{array}{c}\text { Eko. } \\
\text { Olumsuz }\end{array}$ & $\begin{array}{l}\text { Sos-Kül. } \\
\text { Olumlu }\end{array}$ & $\begin{array}{l}\text { Sos-Kül. } \\
\text { Olumsuz }\end{array}$ \\
\hline Cittaslow & $.730^{* * *}$ & & & & & & \\
\hline $\begin{array}{c}\text { Çev. } \\
\text { Olumlu }\end{array}$ & $.616^{* *}$ & $.749^{* * *}$ & & & & & \\
\hline $\begin{array}{c}\text { Çev. } \\
\text { Olumsuz }\end{array}$ & -.085 & $-.107^{*}$ & $.804^{* * *}$ & & & & \\
\hline $\begin{array}{c}\text { Eko. } \\
\text { Olumlu }\end{array}$ & $.602^{* *}$ & $.610^{* *}$ & $-.145^{* *}$ & $.718^{* * *}$ & & & \\
\hline $\begin{array}{c}\text { Eko. } \\
\text { Olumsuz }\end{array}$ & .061 & $.120^{*}$ & $.242^{* *}$ & $.189^{* * *}$ & $.738^{* * *}$ & & \\
\hline $\begin{array}{l}\text { Sos-Kül. } \\
\text { Olumlu }\end{array}$ & $.542^{* *}$ & $.532^{* *}$ & -.067 & $.610^{* *}$ & .062 & $.779^{* * *}$ & \\
\hline $\begin{array}{l}\text { Sos-Kül. } \\
\text { Olumsuz }\end{array}$ & $-.210^{* *}$ & $-.146^{* *}$ & $.508^{* *}$ & $-.188^{* *}$ & $.339^{* *}$ & -.097 & $.785^{* * *}$ \\
\hline relasyon & düzey & anlam & lı (2-yönlü). & & & & \\
\hline
\end{tabular}

Ayrıştırıcı geçerliliği onaylamak için Fornell ve Larcker kriteri de kontrol edilmiştir. Tablo 3'te faktör isimlerinin altında $\left(^{* * *}\right)$ verilen değerler incelendiğinde, .718 ile .804 arasında değişen AVE değerlerinin karekökünü ifade eden Fornell ve Larcker katsayılarının, boyutlar arasındaki ilişki katsayılarından daha yüksek olduğu (Hair, Hult, Ringle ve Sarstedt, 2017) ve ayrıştırıcı geçerliliği sağladığ görülmektedir.

Katılımcların anket formunda yer alan ifadelere ilişkin görüşlerini belirlemek amacıyla, anket formunda yer alan her bir maddeye ilişkin değerlendirmeleri frekans ve yüzde değerleri ile birlikte aritmetik ortalama ve standart sapma değerleri ile birlikte Tablo 4 aracilığıyla paylaşılmıştır.

Araştırma ölçeklerinde yer alan ifadelere katılım düzeylerine göre elde edilen sonuçlar incelendiğinde yavaş şehir ağına katılım kapsamında en fazla katılım gösterilen ifadeler "Cittaslow, turist sayısının artışında etkili bir modeldir ( $\bar{\chi}$ : 3.78)", "Yaşadı̆̆ım şehrin Cittaslow olmasindan memnunum ( $\bar{\chi}$ : 3.78)" ifadeleri olmuştur.

Yavaş şehir ağına katılımın çevresel pozitif-negatif etkilerine ilişkin ifadelerden en fazla katılım gösterilen ifade "Tarihi bina ve yapıların korunmasın teşvik etmektedir ( $\left.\overline{\chi_{:}} 3.73\right)$ " ifadesi olmuştur. Bunun nedeni, Göynük'ün kentsel sit alanı ilan edilip koruma altına alınmış olması ve koruma altına alınan bölgede herhangi bir yapım ve yıkım çalışmasının yasaklanmış olması olarak 
değerlendirilebilir. Yavaş şehir ağına katılımın çevresel pozitif-negatif etkilerine ilişkin ifadelerden en az katılım gösterilen ifade "Doğayı (bitkiler, hayvanlar, ekosistem) olumsuz etkilemektedir ( $\bar{\chi}: 2.25)$ " ifadesi olmuştur.

Tablo 4.Katılımcıların Yavaş Şehir Ağına Katılımın Destinasyona Etkilerine İlişkin Görüşleri

\begin{tabular}{|c|c|c|c|c|c|c|c|c|c|c|c|c|c|}
\hline \multirow[b]{2}{*}{ Faktörler } & \multirow[b]{2}{*}{ İfadeler } & \multicolumn{2}{|c|}{1} & \multicolumn{2}{|c|}{2} & \multicolumn{2}{|c|}{3} & \multicolumn{2}{|c|}{4} & \multicolumn{2}{|c|}{5} & \multirow[b]{2}{*}{$\bar{X}$} & \multirow[b]{2}{*}{ s.s. } \\
\hline & & f & $\%$ & f & $\%$ & f & $\%$ & f & $\%$ & $\mathbf{F}$ & $\%$ & & \\
\hline \multirow{4}{*}{$\begin{array}{c}\text { Yavaş Şehir Ağına } \\
\text { Katılım }\end{array}$} & Yşa1 & 28 & 7.5 & 27 & 7.2 & 54 & 14.4 & 154 & 41.2 & 111 & 29.7 & 3.78 & 1.16 \\
\hline & Yşa2 & 22 & 5.9 & 38 & 10.2 & 76 & 20.3 & 145 & 38.8 & 93 & 24.9 & 3.66 & 1.13 \\
\hline & Yşa3 & 30 & 8.0 & 36 & 9.6 & 112 & 29.9 & 115 & 30.7 & 81 & 21.7 & 3.48 & 1.16 \\
\hline & Yşa4 & 32 & 8.6 & 28 & 7.5 & 56 & 15.0 & 130 & 34.8 & 128 & 34.2 & 3.78 & 1.23 \\
\hline \multirow{4}{*}{$\begin{array}{l}\text { Yavaş Şehir A ğına } \\
\text { Katılımın Olumlu } \\
\text { Çevresel Etkileri }\end{array}$} & Çev.olumlu1 & 31 & 8.3 & 27 & 7.2 & 86 & 23.0 & 130 & 34.8 & 100 & 26.7 & 3.64 & 1.18 \\
\hline & Çev. olumlu2 & 22 & 5.9 & 40 & 10.7 & 92 & 24.6 & 127 & 34.0 & 93 & 24.9 & 3.61 & 1.14 \\
\hline & Çev. olumlu3 & 27 & 7.2 & 50 & 13.4 & 99 & 26.5 & 122 & 32.6 & 76 & 20.3 & 3.45 & 1.16 \\
\hline & Çev. olumlu4 & 24 & 6.4 & 42 & 11.2 & 57 & 15.2 & 138 & 36.9 & 113 & 30.2 & 3.73 & 1.18 \\
\hline \multirow{4}{*}{$\begin{array}{l}\text { Yavaş Şehir A ğına } \\
\text { Katılımın Olumsuz } \\
\text { Çevresel Etkileri }\end{array}$} & Çev.olumsuz1 & 114 & 30.5 & 123 & 32.9 & 63 & 16.8 & 33 & 8.8 & 41 & 11.0 & 2.36 & 1.29 \\
\hline & Çev. olumsuz2 & 128 & 34.2 & 126 & 33.7 & 50 & 13.4 & 38 & 10.2 & 32 & 8.6 & 2.25 & 1.26 \\
\hline & Çev. olumsuz3 & 105 & 28.1 & 128 & 34.2 & 64 & 17.1 & 46 & 12.3 & 31 & 8.3 & 2.38 & 1.24 \\
\hline & Çev. olumsuz4 & 102 & 27.3 & 108 & 28.9 & 71 & 19.0 & 44 & 11.8 & 49 & 13.1 & 2.54 & 1.34 \\
\hline \multirow{5}{*}{$\begin{array}{l}\text { Yavaş Şehir Ağına } \\
\text { Katılımın Olumlu } \\
\text { Ekonomik Etkileri }\end{array}$} & Eko. olumlu1 & 26 & 7.0 & 16 & 4.3 & 74 & 19.8 & 130 & 34.8 & 128 & 34.2 & 3.85 & 1.14 \\
\hline & Eko. olumlu2 & 24 & 6.4 & 35 & 9.4 & 76 & 20.3 & 136 & 36.4 & 102 & 27.3 & 3.68 & 1.15 \\
\hline & Eko. olumlu3 & 19 & 5.1 & 33 & 8.8 & 80 & 21.4 & 139 & 37.2 & 103 & 27.5 & 3.73 & 1.10 \\
\hline & Eko. olumlu4 & 33 & 8.8 & 51 & 13.6 & 101 & 27.0 & 111 & 29.7 & 77 & 20.6 & 3.39 & 1.20 \\
\hline & Eko. olumlu5 & 30 & 8.0 & 55 & 14.7 & 113 & 30.2 & 96 & 25.7 & 79 & 21.1 & 3.37 & 1.21 \\
\hline \multirow{3}{*}{$\begin{array}{l}\text { Yavaş Şehir Ağına } \\
\text { Katılımın Olumsuz } \\
\text { Ekonomik Etkileri }\end{array}$} & Eko. olumsuz1 & 33 & 8.8 & 46 & 12.3 & 105 & 28.1 & 107 & 28.6 & 82 & 21.9 & 3.42 & 1.21 \\
\hline & Eko. olumsuz2 & 49 & 13.1 & 79 & 21.1 & 107 & 28.6 & 83 & 22.2 & 56 & 15.0 & 3.04 & 1.24 \\
\hline & Eko. olumsuz3 & 42 & 11.2 & 107 & 28.6 & 109 & 29.1 & 62 & 16.6 & 54 & 14.4 & 2.94 & 1.21 \\
\hline \multirow{4}{*}{$\begin{array}{c}\text { Yavaş Şehir Ağına } \\
\text { Katılımın Olumlu } \\
\text { Sosyo-Kültürel } \\
\text { Etkileri }\end{array}$} & Sos-Kül. olumlu1 & 48 & 12.8 & 28 & 7.5 & 83 & 22.2 & 114 & 30.5 & 101 & 27.0 & 3.51 & 1.30 \\
\hline & Sos-Kül. olumlu2 & 25 & 6.7 & 53 & 14.2 & 89 & 23.8 & 122 & 32.6 & 85 & 22.7 & 3.50 & 1.18 \\
\hline & Sos-Kül. olumlu3 & 34 & 9.1 & 58 & 15.5 & 93 & 24.9 & 121 & 32.4 & 68 & 18.2 & 3.35 & 1.20 \\
\hline & Sos-Kül. olumlu4 & 56 & 15.0 & 70 & 18.7 & 111 & 29.7 & 71 & 19.0 & 66 & 17.6 & 3.05 & 1.29 \\
\hline \multirow{4}{*}{$\begin{array}{l}\text { Yavaş Şehir Ağına } \\
\text { Katılımın Olumsuz } \\
\text { Sosyo-Kültürel } \\
\text { Etkileri }\end{array}$} & Sos- Kül. & 91 & 24.3 & 141 & 37.7 & 74 & 19.8 & 40 & 10.7 & 28 & 7.5 & 2.39 & 1.17 \\
\hline & Sos- Kül. & 127 & 34.0 & 129 & 34.5 & 44 & 11.8 & 39 & 10.4 & 35 & 9.4 & 2.26 & 1.28 \\
\hline & Sos- Kül. & 117 & 31.3 & 128 & 34.2 & 46 & 12.3 & 46 & 12.3 & 36 & 9.6 & 2.34 & 1.29 \\
\hline & Sos- Kül. & 169 & 45.2 & 83 & 22.2 & 43 & 11.5 & 34 & 9.1 & 45 & 12.0 & 2.20 & 1.40 \\
\hline
\end{tabular}

Yavaş şehir ağına katılımın ekonomik pozitif-negatif etkilerine ilişkin ifadelerden en fazla katılım gösterilen ifade ise "Geleneksel ürünlerin üretimini sağlamaktadır ( $\bar{\chi}: 3.85)$ " ifadesi olmuştur. Bu 
durum, Göynük'ün geçmişten süregelen geleneksel dokumalar, ağaç oymacılı̆̆ı, elişi oyalar, yöresel kıyafetler vb. el sanatlarının yanı sıra Türk mutfağı, tarihi, kültürel ve doğa güzellikleri ile bilinen önemli bir turizm destinasyonu (Özdemir, 2009: 92) olarak değerlendirilmesinin kanıtı olarak değerlendirilebilir. Göynük ile özdeşleşmiş dokuma bir ürün olan Tokalı Örtme, Göynük Belediyesi tarafından Türk Patent Enstitüsü'ne Coğrafi İşaretlerin Korunması kapsamında yapılan başvuru sonucunda kabul edilmiştir. Bu sayede Göynük'e özgü geleneksel el sanatlarının yaşatılması konusunda bir adım atılmıştır (goynuk.bel.tr). Aktaş Yasa (2013: 133)'nın çalışmasında Göynük'te ahşap el sanatlarının ve hediyelik eşyaların önem arz ettiği ancak geleneksel olarak üretilen ahşap kaşık ve baston ustalarının giderek azalmakta olduğunu ve bu zanaatla uğraşan ustaların orta yaş ve üzerinde olduklarını belirtmektedir. Bu sebeple yörede geleneksel ahşap iş̧̧iliğinin yaşatılması, yeni ustaların yetişmesinde teşvik edici olunması gerektiği sonucuna varılmıştır. Yavaş şehir ağına katılımın ekonomik pozitif-negatif etkilerine ilişkin ifadelerden en fazla katılım gösterilen bir diğer ifade ise "Yerel ekonomiyi desteklemektedir ( $\bar{\chi}: 3.73)$ " ifadesi olmuştur. Araştırma bulgularını destekler nitelikte olan Zengin ve Genç (2018: 592)'in çalışmasındaki durum değerlendirmelerine göre Göynük'teki tarihi konaklarda konaklamada ve özellikle yiyecek içecek sektöründe bir artış olması, yerel halkın kendi ürettiği ürünleri, mahsulü satabilmesi yavaş şehir ağına katılımın Göynük'e etkisi olduğu şeklindedir.

Tablo 5. Katılımcıların Görüşlerinin Cinsiyet Değişkenine Göre Karşılaştırılması

\begin{tabular}{|c|c|c|c|c|c|c|}
\hline Boyutlar & Cinsiyet & $\mathbf{N}$ & $\overline{\mathrm{X}}$ & s.s. & $\mathrm{T}$ & $\mathbf{P}$ \\
\hline \multirow{2}{*}{ Yavaş Şehir Ağına Katılım } & Erkek & 212 & 3.68 & 1.027 & \multirow[b]{2}{*}{-.014} & \multirow[b]{2}{*}{.989} \\
\hline & Kadın & 162 & 3.67 & .900 & & \\
\hline \multirow[b]{2}{*}{ Olumlu Çevresel Etkiler } & Erkek & 212 & 3.58 & 1.045 & \multirow[b]{2}{*}{.475} & \multirow[b]{2}{*}{.635} \\
\hline & Kadın & 162 & 3.63 & .920 & & \\
\hline \multirow{2}{*}{ Olumsuz Çevresel Etkiler } & Erkek & 212 & 2.35 & 1.110 & \multirow{2}{*}{.649} & \multirow{2}{*}{.517} \\
\hline & Kadın & 162 & 2.42 & 1.030 & & \\
\hline \multirow[b]{2}{*}{ Olumlu Ekonomik Etkiler } & Erkek & 212 & 3.62 & .956 & \multirow[b]{2}{*}{-.489} & \multirow[b]{2}{*}{.625} \\
\hline & Kadın & 162 & 3.58 & & & \\
\hline \multirow{2}{*}{ Olumsuz Ekonomik Etkiler } & Erkek & 212 & 3.07 & .968 & \multirow{2}{*}{1.543} & \multirow{2}{*}{.124} \\
\hline & Kadın & 162 & 3.22 & .916 & & \\
\hline \multirow{2}{*}{$\begin{array}{c}\text { Olumlu Sosyo-Kültürel } \\
\text { Etkiler }\end{array}$} & Erkek & 212 & 3.39 & 1.023 & \multirow{2}{*}{-.807} & \multirow{2}{*}{.420} \\
\hline & Kadın & 162 & 3.30 & 1.110 & & \\
\hline \multirow{2}{*}{$\begin{array}{c}\text { Olumsuz Sosyo-Kültürel } \\
\text { Etkiler }\end{array}$} & Erkek & 212 & 2.30 & 1.108 & \multirow{2}{*}{-.034} & \multirow{2}{*}{.973} \\
\hline & Kadın & 162 & 2.30 & 1.029 & & \\
\hline
\end{tabular}


Yavaş şehir ağına katılımın sosyo-kültürel pozitif-negatif etkilerine ilişkin ifadelerden en fazla katılım gösterilen ifade ise "Kültürel aktivitelerin gelişimini sağlamaktadır $(\bar{\chi}: 3.51)$ " ifadesi olmuştur. Söz konusu ölçekte en az katılım gösterilen ifade "Suç, fuhuş, uyuşturucu gibi sosyal problemlere neden olmaktadır ( $\bar{\chi}: 2.20)$ " ifadesi olmuştur. En az katılım gösterilen bir diğer ifade ise "Kültürel değerlerin yok olmasına neden olmaktadır ( $\bar{\chi}$ : 2.26)" şeklindedir. Sarıyıldız (2019: 79)'ın da çalışmasında yerel halkın en önemli korkusunun, Sakin Kent olgusunun yaşadıkları kentin sosyal, ahlaki ve kültürel yapısında bozulma yaratabileceği algısı olduğu tespit edilmiştir. Ancak bunu destekleyecek herhangi bir verinin olmadığı yerel yöneticiler ile yapılan görüşmelerde dile getirilmiştir. Bu nedenle bu korkularının gerçekliği test edilememiştir.

Yerel halkın yavaş şehir ağına katılıma ilişkin değerlendirmelerinin çeşitli demografik özellikler bakımından farklılaşıp farklılaşmadığı da çalışmada ele alınmıştır. Katılımcıların cinsiyetlerine göre yavaş şehir ağına katılıma ilişkin değerlendirmelerinin farklılaşmadığı tespit edilmiştir.

Katılımcların yaşlarına göre, yavaş şehir ağına katılıma ilişkin görüşlerinin yavaş şehir ağına katılım algisı $(\mathrm{p}=0.000)$, olumlu ekonomik etkiler $(\mathrm{p}=0.004)$ ve olumlu sosyo-kültürel etkiler $(\mathrm{p}=0.000)$ boyutlarında istatistiki olarak anlamlı bir farklılık gösterdiği tespit edilmiştir (Tablo 6). Farklılı̆̆a hangi yaş grubunun neden olduğunu belirlemek amaciyla Tukey testinden yararlanılmıştır. Buna göre yavaş şehir ağına katılım algısında 29 yaşın altındaki katılımcıların görüşlerinin, 30-45 ve 61 ve üstü yaş gruplarındaki katılımclların görüşlerine göre farklılaştığ 1 belirlenmiştir. Olumlu ekonomik etkiler boyutunda ise 18-29 ile 61 ve üzeri yaş gruplarındaki katılımcıların görüşleri birbirinden farklıdır. Olumlu sosyo-kültürel etkileri boyutunda 18-29 yaş grubundaki bireylerin görüşlerinin 30 ve üzerindeki yaş gruplarında yer alan katılımcıların görüşlerine göre farklılık gösterdiği tespit edilmiştir. Katılımcıların görüşleri aritmetik ortalama değerleri bağlamında değerlendirildiğinde Göynük'ün yavaş şehir ağına katılımı algısı ( $\overline{\chi:} 4.08)$, olumlu ekonomik etkiler ( $\bar{\chi}$ : 4.07) ve olumlu sosyo-kültürel etkiler ( $\bar{\chi}$ : 3.91$)$ boyutları için 61 yaş ve üzeri gruba dâhil olan katılımcıların en fazla olumlu düşünceye sahip grubu oluşturdukları görülmektedir. Bunun sebebi olarak ileri yaştaki insanların daha iyimser bir yaklaşım sergiledikleri ve beklentilerinin daha düşük olduğu düşünülebilir. 
Tablo 6. Katılımcıların Yaşlarına Göre Varyans (Anova) Analizi Sonuçları

\begin{tabular}{|c|c|c|c|c|c|c|}
\hline Boyutlar & Yaş & $\mathbf{N}$ & $\overline{\mathrm{X}}$ & s.s. & $\mathbf{F}$ & $\mathbf{P}$ \\
\hline \multirow{6}{*}{ Yavaş Şehir Ağına Katılım } & 17 ve altı & 58 & $3.32 \mathrm{a}$ & 1.088 & \multirow{6}{*}{5.874} & \multirow{6}{*}{.000} \\
\hline & $18-29$ & 88 & $3.45 a$ & 1.038 & & \\
\hline & $30-45$ & 129 & $3.85 \mathrm{bc}$ & .866 & & \\
\hline & 1660 & 67 & 277 & 070 & & \\
\hline & 61 ve üstü & 31 & $4.08 \mathrm{bc}$ & .849 & & \\
\hline & Toplam & 373 & 3.68 & .971 & & \\
\hline \multirow{6}{*}{ Olumlu Ekonomik Etkiler } & 17 ve altı & 58 & $3.53 \mathrm{ac}$ & 1.026 & \multirow{6}{*}{3.876} & \multirow{6}{*}{.004} \\
\hline & $18-29$ & 88 & $3.38 \mathrm{a}$ & .999 & & \\
\hline & $30-45$ & 129 & $3.60 \mathrm{ac}$ & .901 & & \\
\hline & $46-60$ & 67 & $3.76 \mathrm{ac}$ & .842 & & \\
\hline & 61 ve üstü & 31 & $4.07 \mathrm{bc}$ & .802 & & \\
\hline & Toplam & 373 & 3.60 & .942 & & \\
\hline \multirow{7}{*}{ Olumlu Sosyo-Kültürel Etkiler } & 17 ve alt1 & 58 & $3.17 \mathrm{ab}$ & 1.098 & \multirow{7}{*}{6.965} & \multirow{7}{*}{.000} \\
\hline & $18-29$ & 88 & $2.96 a$ & 1.082 & & \\
\hline & $30-45$ & 129 & $3.48 \mathrm{bc}$ & 1.000 & & \\
\hline & & & & & & \\
\hline & $46-60$ & 67 & $3.54 \mathrm{bc}$ & 1.039 & & \\
\hline & 61 ve üstü & 31 & $3.91 \mathrm{c}$ & .822 & & \\
\hline & Toplam & 373 & 3.35 & 1.062 & & \\
\hline
\end{tabular}

Tablo 7, katılımcıların yavaş şehir ağına katılımın destinasyona etkilerine ilişkin görüşlerinin ikamet süresine göre farklılaşma durumunu göstermektedir. Buna göre, yaş değişkenine göre olduğu gibi ikamet süresine göre de sadece yavaş şehir ağına katılım algısı ( $\mathrm{p}=.005<.05)$, olumlu ekonomik $(\mathrm{p}=.025<.05)$ ve sosyo-kültürel etkiler $(\mathrm{p}=.013<.05)$ boyutlarında görüşlerin farklılaştığ 1 tespit edilmiştir. Yavaş şehir ağına katılım algısı ve olumlu ekonomik etkiler boyutlarında farklılığa neden olan grubun belirlenmesinde en küçük anlamlı farklılıklar (LSD) testinden, olumlu sosyo-kültürel etkiler boyutunda ise Tukey testinden yararlanılmıştır. 
Tablo 7. Katılımcıların İkamet Süresine Göre Varyans (Anova) Analizi Sonuçları

\begin{tabular}{|c|c|c|c|c|c|c|}
\hline Boyutlar & İkamet Süresi & $\mathbf{N}$ & $\overline{\mathrm{x}}$ & s.s. & $\mathbf{F}$ & $\mathbf{P}$ \\
\hline \multirow{7}{*}{ Yavaş Şehir Ağına Katılım } & 1 yıldan az & 20 & $4.02 \mathrm{a}$ & .687 & \multirow{7}{*}{3.458} & \multirow{7}{*}{.005} \\
\hline & $1-5$ y1l & 49 & $3.74 \mathrm{ab}$ & 1.066 & & \\
\hline & $6-10$ y1l & 27 & $3.37 \mathrm{~b}$ & .971 & & \\
\hline & $11-15$ yıl & 62 & $3.46 \mathrm{~b}$ & 1.034 & & \\
\hline & $16-24$ y1l & 53 & $3.41 \mathrm{~b}$ & 1.129 & & \\
\hline & 25 yıldan fazla & 163 & $3.83 a$ & .852 & & \\
\hline & Toplam & 374 & 3.67 & .973 & & \\
\hline \multirow{7}{*}{ Olumlu Ekonomik Etkiler } & 1 yildan az & 20 & $3.76 \mathrm{a}$ & .697 & \multirow{7}{*}{2.603} & \multirow{7}{*}{.025} \\
\hline & $1-5$ yıl & 49 & $3.80 \mathrm{a}$ & .982 & & \\
\hline & $6-10$ y1l & 27 & $3.22 b c$ & .932 & & \\
\hline & $11-15$ yıl & 62 & $3.60 \mathrm{ac}$ & .924 & & \\
\hline & 16-24 yıl & 53 & $3.32 \mathrm{bc}$ & 1.088 & & \\
\hline & 25 yıldan fazla & 163 & $3.68 \mathrm{a}$ & .886 & & \\
\hline & Toplam & 374 & 3.60 & .941 & & \\
\hline \multirow{7}{*}{ Olumlu Sosyo-Kültürel Etkiler } & 1 yıldan az & 20 & $3.32 \mathrm{ac}$ & .956 & \multirow{7}{*}{2.917} & \multirow{7}{*}{.013} \\
\hline & $1-5$ y1l & 49 & $3.46 \mathrm{ac}$ & 1.134 & & \\
\hline & $6-10$ yil & 27 & $3.16 \mathrm{ac}$ & .919 & & \\
\hline & $11-15$ y1l & 62 & $3.21 \mathrm{ac}$ & 1.163 & & \\
\hline & $16-24$ yıl & 53 & $2.97 a$ & 1.037 & & \\
\hline & 25 yıldan fazla & 163 & $3.53 b c$ & 1.008 & & \\
\hline & Toplam & 374 & 3.35 & 1.061 & & \\
\hline
\end{tabular}

Yavaş şehir ağına katılım algısı boyutu için, Göynük'te 1 yıldan az süredir ikamet edenlerin görüssleri 6-24 yıldır ikamet edenlerin görüşlerinden farklılaşmaktadır. Bununla birlikte; 5 yıldan az süredir ikamet edenlerin görüşleri ile 25 yıldan fazladır ikamet edenlerin görüşlerinin benzer olduğu söylenebilir. Olumlu sosyo-kültürel etkiler boyutunda ise 25 yıldan fazla süredir ikamet edenlerin görüşleri 16-24 yıldır ikamet edenlerin görüşlerinden farklıdır (Tablo 7). 
Tablo 8.Katılımcıların Eğitim Durumuna Göre Varyans (Anova) Analizi Sonuçları

\begin{tabular}{|c|c|c|c|c|c|c|}
\hline Boyutlar & Eğitim Durumu & $\mathbf{N}$ & $\bar{X}$ & s.s. & $\mathbf{F}$ & $\mathbf{P}$ \\
\hline \multirow{7}{*}{ Yavaş Şehir Ağına Katılım } & İlköğretim & 151 & $3.80 \mathrm{a}$ & .841 & \multirow{7}{*}{4.803} & \multirow{7}{*}{.001} \\
\hline & Lise & 139 & $3.44 b$ & 1.118 & & \\
\hline & Ön Lisans & 28 & $3.61 \mathrm{ab}$ & .991 & & \\
\hline & & & & & & \\
\hline & Lisans & 52 & $3.87 \mathrm{ab}$ & .770 & & \\
\hline & Lisansüstü & 4 & $4.87 \mathrm{ac}$ & .250 & & \\
\hline & Toplam & 374 & 3.67 & & & \\
\hline \multirow{7}{*}{ Olumlu Çevresel Etkiler } & İlköğretim & 151 & $3.68 \mathrm{ac}$ & ,88419 & \multirow{7}{*}{3.921} & \multirow{7}{*}{.004} \\
\hline & Lise & 139 & $3.44 \mathrm{a}$ & 1,06427 & & \\
\hline & Ön Lisans & 28 & $3.30 \mathrm{a}$ & 1,20830 & & \\
\hline & & & & & & \\
\hline & Lisans & 52 & $3.96 \mathrm{bc}$ & 84892 & & \\
\hline & Lisansüstü & 4 & $4.18 \mathrm{ac}$ & ,89849 & & \\
\hline & Toplam & 374 & 3.61 & ,99212 & & \\
\hline
\end{tabular}

Katılımcların eğitim durumlarına göre ifadelere ilişkin görüşleri arasında herhangi bir farklılık olup olmadığını ölçmek için yapılan Varyans Analizi sonucunda; yavaş şehir ağına katılım algısı $(\mathrm{p}=.001<.05)$ ve olumlu çevresel etkiler $(\mathrm{p}=.004<.05)$ boyutlarında görüşler arasında istatistiki olarak anlamlı bir farklılık bulunmuştur. Farklılığa neden olan eğitim durumu grubunu belirlemek için Tukey testinden faydalanılmıştır. Yavaş şehir ağına katılım algısı ile ilgili görüşlerde ilköğretim ( $\bar{\chi}$ : 3.80) ile lise $(\overline{\chi:} 3.44)$ ve lisansüstü $(\bar{\chi}: 4.87)$ ile lise $(\overline{\chi:} 3.44)$ grupları arasında; olumlu çevresel etkilere ilişkin görüşlerde ise lise $(\bar{\chi}: 3.44)$ ile lisans $(\bar{\chi}: 3.96)$ ve önlisans $(\bar{\chi}: 3.30)$ ile lisans $(\bar{\chi}: 3.96)$ düzeyinde eğitim alan bireylerin görüşleri arasında farklılık olduğu görülmüş̧ür (Tablo 8).

\section{SONUÇ}

Yavaş şehir ağına katılımın Göynük'e etkilerinin ele alındığı bu çalışmada, ilgili destinasyonda yaşayan yerel halk hedef kitle olarak belirlenmiş ve 410 katılımcı ile yüz yüze anket uygulaması gerçekleştirilmiştir. Çalışmada Göynük'ün yavaş şehir ağına katılmadan önceki durumu hakkında detaylı bilgi sahibi olan, yavaş şehir ağına katılımın dinamikleri hakkında bilgi sahibi olan ve yavaş şehir ağına katıldıktan sonra oluşabilecek çevresel, ekonomik ve sosyo-kültürel etkiyi değerlendirebilecek kişilere ulaşılması hedeflenmiştir. 374 kişiden elde edilen verilerin analizlere dâhil edilmesiyle yapılan değerlendirme genel hatları itibariyle şunu göstermektedir:

a) Katılımcılar, yavaş şehir ağına katılımdan memnun olduklarını, daha fazla turistin ziyarete geldiğini ifade etmektedirler, 
b) Yavaş şehir ağına katılım sayesinde tarihi bina ve yapıların korunmasının teşvik edildiğini düşünmektedirler,

c) Yavaş şehir ağına katılımın doğayı olumsuz etkilemediğini ifade etmektedirler,

d) Geleneksel ürünlerin üretimi bu sayede teşvik edilmektedir ve kültürel aktivitelerin gelişimi sağlanmaktadır,

e) Yavaş şehir ağına katılımın olumlu ekonomik etkileri konusunda 18-29 yaş grubu ile 61 yaşının üzerindeki bireylerin görüşleri farklıdır. Bunun yanı sıra 61 yaşından daha büyük katılımcılar diğer gruplara göre daha olumlu düşünmektedirler,

f) Göynük'te 1 yıldan daha az süreli ikamet edenlerin görüşleri, daha uzun süredir ikamet edenlere göre istatistiksel açıdan farklılık göstermektedir.

Araştırmanın sonucunda ulaşılan bulgular değerlendirildiğinde yavaş şehir ağına katılımın Göynük'te yerel ekonomiyi desteklediği ve yerel halk için yeni iş fırsatları sağladığı anlaşılmaktadır. Yavaş şehir ağına katılan Göynük ilçesinde geleneksel ürünlerin üretimi ve pazarlanması, yerel kültürün korunması yönünde çabaların sürdürülmeye çalışıldığının bir göstergesidir. Araştırmadan elde edilen bulgulara göre katılımcılar yavaş şehir ağına katılımın ekonomik etkileri boyutu ile ilgili olarak bölgedeki ürün ve hizmet fiyatlarını nispeten arttırdığını ve hayat pahalılığına neden olduğunu düşünmektedirler. Diğer taraftan, yerel halk için yeni iş fırsatları oluşturduğuna ve bölgeye daha fazla yatırımın yapılmasına zemin hazırladığına ilişkin olumlu görüşler olduğu belirlenmiştir.

Araştırma sonuçlarını destekler nitelikte çalışmalar da mevcuttur. Dural ve Köseoğlu (2017)'nun çalışmalarında Göynük'ün destinasyon olarak tercih edilmesinde sırasıyla havasının ve suyunun temiz olması, halkın ve esnafın misafirperverliği, trafik gürültüsünün az olması, sakin şehir unvanına sahip olması, şehrin rahatlıkla yürüyerek gezilebilecek olması, halkın kullanabileceği yeşil alanların varlığı, şehir merkezinin sit alanı olması ve tarihi dokunun korunması hususlarının etkili olduğu sonucuna varılmıştır. Ayrıca katılımcılar el sanatları, dokumacılığın hala devam ettiğini, yavaş şehir müracaatı öncesinde halka turizm eğitimi verildiğini, şehrin eski Osmanlı geleneklerini koruduğunu ve çok fazla değişim yaşanmayacağı çünkü yeni nesle aktarım yapıldığını ifade etmişlerdir. Zengin ve Genç (2018)'in çalışmalarının sonucuna göre Göynük'ün yavaş şehir ağına katılması özel sektör temsilcileri tarafından olumlu karşılanmıştır. Yavaş şehir ağına katılım ile birlikte turizm talebinde bir artış yaşandığı, oluşan talebe karşı kentsel yaşamda da değişimler yaşanmıştır. Esnafın hafta sonu dükkanlarını açması, köylünün ürettiği mahsulü satmasının yanı sıra yerel yönetim öncülüğünde de esnafın elektrikli mobilete geçmesi, kartvizit ve internet sitelerinde yavaş şehir logosunun eklenmesi gibi değişiklikler yaşanmaktadır. Göynük destinasyonunun konaklama kapasitesinin yetersizliği, aktivite eksikliği gibi sebeplerle uğrak noktası olmanın ötesine geçilememesini düşünen temsilciler de olmuştur. Şengül, Bayhan ve Yücel (2018)'in çalışmalarında yerel turizm paydaşları ile gerçekleştirdikleri görüşmeler sonucunda Göynük'ün algılarındaki yeri sakinlik, maneviyat, tarih ve kültür ile doğal güzellikler şeklindedir. Akşemseddin Türbesi'nin bölge turizmi ve kültürü için önemli olduğu, yavaş şehir olmanın tanınırlık ve ziyaretçi artışına sebep olduğu da çıkan sonuçlardandır. Sarıyıldız (2019), yerel halk, yerel işletme sahipleri ve belediye başkanıyla yavaş şehir algılarını ve yaşam kalitelerini ortaya koymak için yaptığı görüşmeler sonucunda katılımcılardan \%91.01'inde yavaş şehir Göynük'te turist sayısı ve yöre halkının kazancında gözle görülür bir artış gözlemlemiştir. Turist sayısının artışıyla ticari işletme sayısı da artmış, ilçede yöresel ürünlerin üretimi ve satışları çoğalmıştır. Yöresel ürünler sayesinde yöre kadınları için gelir kapısı oluşmuştur. İnanç turizmiyle ilgi gören Göynük yavaş şehir unvanı aldıktan sonra daha da ilgi görmeye başlamıştır. Katılımcıların \%9.09'u ise herhangi bir gelişim ve değişim gözlemlememiş, genel olarak olumsuz düşünceleri turist sayısının beraberinde getireceği gürültü 
ve çevre kirliliğiyle birlikte turistlerin konaklaması amacıyla yapılan yeni yapıların şehrin görünümünü bozduğu yönündedir. Bunun yanı sıra turistlerin ahlaki davranışlarının yerel halktan farklı olması sebebiyle ahlaki yozlaşmaya sebep olacağı düşünülmektedir.

Çalışmada elde edilen bulguların literatüre katkısının yanında, ilgili işletmelere, kurum ve kuruluşlara, araştırmanın gerçekleştirildiği bölgeye ve bölgede yaşayanlara katkı sağlayacağ 1 düşünülmektedir. Belirli aralıklarla farklı değişkenleri ele alarak yerel halka yönelik gerçekleştirilecek çalışmalarla yavaş şehir ağının bölgelere ve turizme etkileri ortaya konulabilir.

\section{KAYNAKÇA}

Acar, A. (2018). Yeni Daha İyi Bir Yaşam Stili Olarak Yavaş Şehir ve Turizm Üzerine Etkisi: Türkiye Örneği. International Journal of Tourism, Economic and Business Sciences, 2 (2), 130-136.

Akman, E. (2018). Türkiye'deki Yavaş Şehirlerin Politika Uygulamaları Üzerinden Bir Analiz. EKEV Akademi Dergisi, 22 (76), 79-107.

Aktaş Yasa, A. (2013). Göynük'te Geleneksel Ahşap İşçiliği. Göynük El Sanatları Paneli ve Çalıştayı Bildirileri, Göynük Belediyesi Yayını No:2, 117-134, Ankara.

Aktaş Yasa, A. (2013). Kültürel Zenginlikleri ile Göynük. Göynük El Sanatları Paneli ve Çalıştayı Bildirileri, Göynük Belediyesi Yayını No:2, 17-46, Ankara.

Altunışık, R., Coşkun. R., Bayraktaroğlu. S. ve Yıldırım. E. (2012). Sosyal Bilimlerde Araştırma Yöntemleri SPSS Uygulamal. Sakarya: Sakarya Kitabevi.

Baytok, A., Zorlu, Ö. ve Avan, A. (2018). Turizmde Sürdürülebilirlik Kapsamında Cittaslow ve Toplum Temelli Turizm İlişkisinin Kavramsal Olarak Incelenmesi. İçinde: Innovation and Global Issues in Social Sciences IV, Bildiriler Kitabı, 22-24 Kasım, Lara, Antalya.

Berkün, S. (2018). Bir Kent Yönetim Modeli Olarak Türkiye'de Yavaş Şehirler ve Halkın Farkındalığı: Isparta Örneği, Business \& Management Studies: An International Journal, 6 (4): 14171433.

Coşar, Y. (2013). Yavaş Şehir (Cittaslow) Olgusunun Turist Davranışları ve Yerel Halkın Kentsel Yaşam Kalitesi Algısına Etkileri (Doktora Tezi). Dokuz Eylül Üniversitesi, Sosyal Bilimler Enstitüsü, Turizm İşletmeciliği Anabilim Dalı, İzmir.

Coşar, Y. (2019). Yavaş Şehir-Sürdürülebilir Turizm Paradoksu Üzerine Eleştirel Bir Bakış. Journal of Tourism Theory and Research, 5 (1), 40-50.

Çakıcı, A. C., Yenipınar, U. ve Benli, S. (2014). Yavaş Şehir Hareketi: Seferihisar Halkının Tutum ve Algıları ile Yaşam Doyumları. Journal of Travel and Hospitality Management, 11 (3), 26-41.

Çerçi, A. (2013). Destinasyon Markalama ve Yavaşşehir Seferihisar'ın Destinasyon Marka İmajı (Yüksek Lisans Tezi). Hacettepe Üniversitesi Sosyal Bilimler Enstitüsü İşletme Anabilim Dalı, Turizm İşletmeciliği Uzmanlığı, Ankara.

Çetinkaya Usta, M. (2017). Geçiş Toplumunda Dinî Hayat: Göynük Örneği (Yüksek Lisans Tezi), Marmara Üniversitesi Sosyal Bilimler Enstitüsü, İstanbul.

Çıtak, Ş. (2016). Sakin Şehirler Hızlı Turistler. İnsan ve Toplum Bilimleri Araştırmaları Dergisi, 5 (8), 2692-2706.

Dural, G. ve Köseoğlu, E. (2017). Destinasyon Tercihinde Kentsel Kimliğin Etkisi: Destinasyon Tercihinde Kentsel Kimliğin Etkisi: Sakin Şehir Göynük Örneği. 4. Disiplinlerarası Turizm Araştırmaları Kongresi Bildiri Kitabı, 63- 78, Ankara. 
Dural, G. (2019). Aşinalığın Mekânsal Okunabilirliğe Etkisi: Göynük'teki Öznel ve Nesnel İşaret Öğeleri (Yüksek Lisans Tezi), Fatih Sultan Mehmet Vakıf Üniversitesi, Lisansüstü Eğitim Enstitüsü, İstanbul.

Farhadi Andarabi, F. (2012). Cittaslow Markasına Sahip Şehirlerde Yerel Halkın Turizme Yaklaşımı Üzerine Bir Analiz: Seferihisar Örneği (Yüksek Lisans Tezi), Gazi Üniversitesi Eğitim Bilimleri Enstitüsü, Ankara.

Güneş, N. (2014). Yerel Halkın Turizm Algııı ve Turizme Katılımı: Antalya Konyaaltı ve Kepez İlçesi Örneği (Yüksek Lisans Tezi), Akdeniz Üniversitesi Sosyal Bilimler Enstitüsü, Antalya.

Hair, J. F., Hult, G. T. M., Ringle, C. M. and Sarstedt, M. (2017). A Primer on Partial Least Squares Structural Equation Modeling (PLS-SEM) (2nd Ed.). Los Angeles: Sage Publications, Inc.

Hatipoğlu, B. (2016). "Cittaslow": Quality of Life and Visitor Experiences. Tourism Planning $\mathcal{E}$ Development, 12(1), 20-36, DOI: 10.1080/21568316.2014.960601.

http://www.bolu.gov.tr/nufus-yapisi/ (Erişim Tarihi: 17.04.2020).

http://cittaslow.org/ (Erişim Tarihi: 21.11.2019).

https://cittaslowturkiye.org/cittaslow-goynuk/ (Erişim Tarihi: 21.11.2019).

https://goynuk.bel.tr/ Erişim Tarihi: (14.11.2019).

Kartal, G. ve Öztürk, S. (2016). Sürdürülebilir Turizm Bağlamında Cittaslow "Yavaş Şehir" Hareketi ve Bölgesel Kalkınma İlişkisi. ÜNIDAP Uluslararası Bölgesel Kalkınma Konferansı, 344-363.

Kılıç Benzer, A. N. (2007). Bolu-Göynük ve Yakın Çevresi Doğal ve Kültürel Kaynaklarının Ekoturizm Açısından Değerlendirilmesi, Ankara Üniversitesi Bilimsel Araştırma Projeleri Kesin Raporu, Ankara.

Koç, V. ve Baz, İ. (2020). Türkiye'de Sakin Şehir Hareketine Üyelik Süreci ve Üyeliğin Etkileri. İstanbul Ticaret Üniversitesi Teknoloji ve Uygulamalı Bilimler Dergisi, 2 (2), 57-67.

Levent, F. (2019). Yerel Halkın Yavaş Şehir Hareketine İlişkin Algıları: Akyaka Örneği (Yayınlanmamış Yüksek Lisans Tezi), Bursa Uludağ Üniversitesi Sosyal Bilimler Enstitüsü, Bursa.

Numanoğlu, E. ve Güçer, E. (2018). Yerel Halk Açısından Yavaş Şehir Akımı Algısı: Perşembe Örneği. Journal of Multidisciplinary Academic Tourism, 3 (2), 11-22.

Özdemir, M. (2009). Bolu İli Göynük İlçesi Geleneksel Kadın Başlığı, e-Journal of New World Sciences Academy, 4 (1), 92-104.

Park, E. and Kim, S. (2016). The Potential of Cittaslow for Sustainable Tourism Development: Enhancing Local Community's Empowerment, Tourism Planning \& Development, 13 (3), 351-369, DOI: $10.1080 / 21568316.2015 .1114015$

Presenza, A., Abbate, T. and Micera, R. (2015) The Cittaslow Movement: Opportunities and Challenges for the Governance of Tourism Destinations, Tourism Planning E Development, 12:4, 479-488, DOI: 10.1080/21568316.2015.1037929

Sarıyıldız, M. (2019). Sakin Kent Algısı Üzerine Bir Araştırma: "Bolu-Göynük Örneği" (Yüksek Lisans Tezi), Kırıkkale Üniversitesi Sosyal Bilimler Enstitüsü, Kırıkkale.

Semmens, J. and Freeman, C. (2012). The Value of Cittaslow as an Approach to Local Sustainable Development: A New Zealand Perspective, International Planning Studies, 17 (4), 353-375, DOI: 10.1080/13563475.2012.726851

Şahin, İ. ve Kutlu, S. Z. (2014). Cittaslow: Sürdürülebilir Kalkınma Ekseninde Bir Değerlendirme. 
Journal of Tourism and Gastronomy Studies, 2 (1), 55-63.

Şengül, S., Bayhan, İ. ve Yücel, R. (2018). Turizm Destinasyonlarında Sürdürülebilir Gelişim: Göynük Yerel Turizm Paydaşları Üzerine Bir Araştırma. Journal of Travel and Hospitality Management, 15 (3), 489-505.

Tabachnick, B. G. and Fidell L. S. (2013). Using Multivariate Satatistics (sixth ed.) Pearson, Boston. Ural, A. ve Kılıç, İ. (2005). Bilimsel Araştırma Süreci ve SPSS ile Veri Analizi. Ankara: Detay Yayıncilik.

Walker, T. B. and Lee, T. J. (2019a). Visitor and Resident Perceptions of the Slow City Movement: The Case of Japan, International Journal of Tourism Sciences, 19 (2), 112-127, DOI: 10.1080/15980634.2019.1621535

Walker, T. B. and Lee, T. J. (2019b). Contributions to Sustainable Tourism in Small Islands: An Analysis of the Cittàslow Movement, Tourism Geographies, DOI: 10.1080/14616688.2019.1654539

Yazıcı, T. ve Keba Ekinci, D. (2017). Yavaş Şehirlerin Kurumsal Web Sitesi Kullanımı Üzerine Bir Inceleme: Cittaslow Türkiye Belediyeleri Web Sitesi Ana Sayfalarının Karşılaştırılması, 1. Uluslararası İletişimde Yeni Yönelimler Konferansı, 179-193.

Zengin, B. ve Genç, K. (2018). Yavaş Şehirlerin (Citta-Slow) Pazarlanması: Göynük Örneği. Manas Sosyal Araştırmalar Dergisi, 7 (2), 585-599. 